\title{
Bhc-diol as a Photolabile Protecting Group for Aldehydes and Ketones
}

\author{
Min Lu, Olesya D. Fedoryak, Brent R. Moister, and Timothy M. Dore* \\ Department of Chemistry, University of Georgia, Athens, GA 30602-2556 \\ tdore@chem.uga.edu
}

All reagents and solvents were purchased from commercial sources and used without further purification with the following exceptions. Toluene was dried by passing it through activated alumina under nitrogen pressure (Solv-Tek, Berryville, VA). Pyridine and acetonitrile were refluxed with calcium hydride under nitrogen, and then distilled. ${ }^{1} \mathrm{H}$ NMR and ${ }^{13} \mathrm{C}$ NMR spectra were recorded on a Varian MercuryPlus $400 \mathrm{MHz}$ spectrometer. FTIR spectra were recorded on a Bruker Vector 22 spectrophotometer. UV spectra were recorded on a Cary 300 Bio UVVisible spectrophotometer (Varian). HPLC analysis (analytical and preparative) was performed on a Varian ProStar HPLC system with an autosampler and diode array detector using Microsorb C-18 reverse phase columns. Mass spectrometry was performed on a Sciex API-1 Plus quadrupole mass spectrometer with an electrospray ionization source. KMOPS buffer consisted of $100 \mathrm{mM} \mathrm{KCl}$ and $10 \mathrm{mM}$ MOPS titrated to $\mathrm{pH} 7.2$ with $\mathrm{KOH}$. Thin layer and column chromatography were performed on precoated silica gel $60 \mathrm{~F}_{254}$ plates (EM Science or Sorbent Technologies) and 230-400 mesh silica gel 60 (EM Science), respectively. Melting points were determined on a Mel-Temp (Laboratory Devices, Inc.), and are uncorrected.

6-Bromo-4-chloromethyl-7-acetyloxycoumarin (11). Under a nitrogen atmosphere, 6-bromo4-chloromethyl-7-hydroxycoumarin $\mathbf{( 1 0}, 780 \mathrm{mg}, 2.69 \mathrm{mmol})$ and acetic anhydride $(0.64 \mathrm{~mL}, 6.8$ mmol) were stirred in anhydrous pyridine $(3 \mathrm{~mL})$ for $4 \mathrm{~h}$. The pyridine was removed under vacuum, and the resulting crude product was purified by flash chromatography through silica gel (hexanes/EtOAc, 1:1) to afford 11 as a white solid $\left(760 \mathrm{mg}, 85 \%, \mathrm{mp} 180{ }^{\circ} \mathrm{C} \mathrm{dec}\right) .{ }^{1} \mathrm{H}$ NMR $\left(\mathrm{CDCl}_{3}\right) \delta 7.91(1 \mathrm{H}, \mathrm{s}), 7.21(1 \mathrm{H}, \mathrm{s}), 6.58(1 \mathrm{H}, \mathrm{s}), 4.63(2 \mathrm{H}, \mathrm{s}), 2.41(3 \mathrm{H}, \mathrm{s}) ;{ }^{13} \mathrm{C}$ NMR $(100$ $\left.\mathrm{MHz}, \mathrm{CDCl}_{3}\right)$ 168.06, 159.45, 153.68, 150.99, 148.31, 128.61, 116.96, 116.59, 113.30, 112.40, 41.19, 21.03; FTIR (neat) 1732, 1599, 1396, 1217, 1181, 1137, 1022, 906, 862, 728, 658, 629 $\mathrm{cm}^{-1}$.

Phosphonium salt 12. Under a nitrogen atmosphere, a mixture of 6-bromo-4-chloromethyl-7acetyloxycoumarin $(\mathbf{1 1}, 650 \mathrm{mg}, 1.96 \mathrm{mmol})$ and triphenyl phosphine $(1.028 \mathrm{~g}, 3.92 \mathrm{mmol})$ in acetonitrile was heated to $85{ }^{\circ} \mathrm{C}$. After $30 \mathrm{~min}$, the suspended mixture dissolved. Heating was continued for $18 \mathrm{~h}$, during which time the white phosphonium salt precipitated. The mixture was cooled, filtered, and the filtrand was washed several times with boiling benzene to yield phosphonium salt 12 as a white solid (948 mg, 82\%), which was carried to the next step without further purification.

6-Bromo-4-(1,2-ethylene)-7-hydroxycoumarin (Bhc-ethylene, 13). Phosphonium salt 12 (310 $\mathrm{mg}, 0.522 \mathrm{mmol}$ ) was taken up in a $37 \%$ formaldehyde solution ( $4 \mathrm{~mL}$, aqueous). The mixture was stirred for $15 \mathrm{~min}$, and then an aqueous solution of $15 \% \mathrm{Na}_{2} \mathrm{CO}_{3}(0.5 \mathrm{~mL})$ was added intermittently by a syringe. Each subsequent addition was made after the orange-yellow color of the phosphorone formed had disappeared. When the addition of the base was complete, the mixture was stirred at room temperature for $2 \mathrm{~h}$, and then extracted with $\mathrm{CHCl}_{3}(3 \times)$. The 
combined $\mathrm{CHCl}_{3}$ extracts were dried over anhydrous sodium sulfate and evaporated. The crude product was purified by flash chromatography through silica gel (hexanes/EtOAc, 6:4) to afford 13 as a white solid $\left(100 \mathrm{mg}, 72 \%, \mathrm{mp} 210-230{ }^{\circ} \mathrm{C} \mathrm{dec}\right) .{ }^{1} \mathrm{H}$ NMR $\left(\left(\mathrm{CD}_{3}\right)_{2} \mathrm{CO}\right) \delta 8.00(1 \mathrm{H}, \mathrm{s})$, $7.21(1 \mathrm{H}, \mathrm{dd}, J=17.2,11.6 \mathrm{~Hz}), 6.94(1 \mathrm{H}, \mathrm{s}), 6.35(1 \mathrm{H}, \mathrm{s}), 6.14(1 \mathrm{H}, \mathrm{dd}, J=17.2,1.2 \mathrm{~Hz}), 5.77$ $(1 \mathrm{H}, \mathrm{dd}, J=11.2,0.8 \mathrm{~Hz}) ;{ }^{13} \mathrm{C} \mathrm{NMR}\left(100 \mathrm{MHz},\left(\mathrm{CD}_{3}\right)_{2} \mathrm{CO}\right) 160.08,157.31,154.88,150.18$, 130.47, 129.19, 123.31, 112.80, 108.38, 106.08, 103.87; FTIR (neat) 3392, 1700, 1607, 1412, 1365, 1310, 1268, 1223, 1155, $954 \mathrm{~cm}^{-1}$; MS m/z $267\left(\mathrm{MH}^{+},{ }^{81} \mathrm{Br}\right), 265\left(\mathrm{MH}^{+},{ }^{79} \mathrm{Br}\right)$.

6-Bromo-4-(1,2-dihydroxyethyl)-7-hydroxycoumarin (Bhc-diol, 14). Bhc-ethylene (13, 200 $\mathrm{mg}, 0.749 \mathrm{mmol}$ ) and one small piece of osmium tetroxide (which was not weighed because of its toxicity and the difficulty in accurately weighing it, due to rapid sublimation) were added to a solution of 4-methylmorpholine $N$-oxide monohydrate $(101 \mathrm{mg}, 0.747 \mathrm{mmol})$ in water $(4 \mathrm{~mL})$ and acetone $(2 \mathrm{~mL})$. The resulting solution was vigorously stirred at room temperature for $18 \mathrm{~h}$, during which time the mixture turned a light brown color. The reaction was neutralized to $\mathrm{pH} 7$ with $3 \mathrm{~N}$ sulfuric acid. The acetone was evaporated, and the resulting aqueous solution was extracted with EtOAc $(5 \times)$. The combined organic extracts were evaporated, and the resulting crude product was purified by flash chromatography through silica gel (hexanes/EtOAc, 2:8) to afford 14 as a white solid $\left(180 \mathrm{mg}, 80 \%\right.$, mp 200-220 $\left.{ }^{\circ} \mathrm{C} \mathrm{dec}\right) .{ }^{1} \mathrm{H}$ NMR $\left(\left(\mathrm{CD}_{3}\right)_{2} \mathrm{CO}\right) \delta 8.05$ $(1 \mathrm{H}, \mathrm{s}), 6.92(1 \mathrm{H}, \mathrm{s}), 6.41(1 \mathrm{H}, \mathrm{s}), 5.13(1 \mathrm{H}, \mathrm{dd}, J=4.4,4.4 \mathrm{~Hz}), 3.88(1 \mathrm{H}, \mathrm{dd}, J=12.0,4.4 \mathrm{~Hz})$, $3.71(1 \mathrm{H}, \mathrm{dd}, J=11.2,5.6 \mathrm{~Hz}) ;{ }^{13} \mathrm{C}$ NMR $\left(100 \mathrm{MHz},\left(\mathrm{CD}_{3}\right)_{2} \mathrm{CO}\right) 160.78,157.55,156.15,155.57$, 129.94, 113.09, 111.09, 106.56, 104.44, 71.42, 67.03; FTIR (neat) 3332, 1726, 1604, 1437, 1158, 1120, 882, 773, 695, $540 \mathrm{~cm}^{-1}$; MS m/z $303\left(\mathrm{MH}^{+},{ }^{81} \mathrm{Br}\right), 301\left(\mathrm{MH}^{+},{ }^{79} \mathrm{Br}\right)$.

General Procedure for the Synthesis of 6-Bromo-7-Hydroxycoumarin Acetals and Ketals. Under a nitrogen atmosphere, aldehyde or ketone 15 (2 equiv.) in $10 \mu \mathrm{L}$ of 1-butanol was added to a mixture of Bhc-diol (14, 1 equiv.), pyridinium $p$-toluenesulfonate (PPTS, 1 equiv), and anhydrous $\mathrm{MgSO}_{4}(100 \mathrm{mg})$ in anhydrous toluene $(2 \mathrm{~mL})$. The reaction mixture was stirred at $110{ }^{\circ} \mathrm{C}$ for $8 \mathrm{~h}$, and then filtered, washing the solid filtrand with $\mathrm{CHCl}_{3}$. The filtrate was evaporated, and the resulting crude product was purified by flash chromatography through silica gel (EtOAc/hexanes, 1:1) to give the Bhc-protected aldehyde or ketone 16. With the exception of 16d, all Bhc-diol protected aldehydes and ketones were isolated as a mixture of diastereomers.

Bhc-diol-benzaldehyde (16a). Bhc-diol (15 mg, $0.05 \mathrm{mmol})$, PPTS (13 mg, $0.05 \mathrm{mmol})$, benzaldehyde (15a, $10 \mu \mathrm{L}, 0.10 \mathrm{mmol})$; yield $=11 \mathrm{mg}\left(57 \%, \mathrm{mp} 106-180{ }^{\circ} \mathrm{C} \mathrm{dec}\right) .{ }^{1} \mathrm{H}$ NMR $\left(\mathrm{CDCl}_{3}\right) \delta 7.50(6 \mathrm{H}, \mathrm{m}),[7.07(\mathrm{~s}), 7.06(\mathrm{~s})(1 \mathrm{H})],[6.67(\mathrm{~s}), 6.55(\mathrm{~s})(1 \mathrm{H})],[6.14(\mathrm{~s}), 6.02(\mathrm{~s})$ $(1 \mathrm{H})], 5.40(1 \mathrm{H}, \mathrm{m}),[4.73(\mathrm{dd}, J=7.6,7.6 \mathrm{~Hz}), 4.57(\mathrm{dd}, J=8.4,8.4 \mathrm{~Hz})(1 \mathrm{H})],[4.09(\mathrm{dd}, J=$ 8.4, $5.6 \mathrm{~Hz}), 3.86(\mathrm{dd}, J=7.2,7.2 \mathrm{~Hz})(1 \mathrm{H})] ;{ }^{13} \mathrm{C}$ NMR $\left(100 \mathrm{MHz}, \mathrm{CDCl}_{3}\right)(160.44,160.33)$, (155.37, 155.27), (154.91, 154.85), (152.14, 151.85), 136.57, 135.58, (129.96, 129.76), (128.68, 128.62), 126.67, (126.54, 126.44), (112.24, 112.15), 110.70, 109.60, 106.68, 105.18, (104.74, 104.67), (73.80, 73.30), (70.62, 70.23); FTIR (neat) 3407, 2922, 1698, 1602, 1396, 1308, 1271, $1222,1153,1095,1021,873,756,699 \mathrm{~cm}^{-1}$; MS m/z $391\left(\mathrm{MH}^{+},{ }^{81} \mathrm{Br}\right), 389\left(\mathrm{MH}^{+},{ }^{79} \mathrm{Br}\right)$.

Bhc-diol-piperonal (16b). Bhc-diol (15 mg, $0.05 \mathrm{mmol})$, PPTS (13 mg, $0.05 \mathrm{mmol})$, piperonal $(\mathbf{1 5 b}, 15 \mathrm{mg}, 0.10 \mathrm{mmol})$; yield $\left.=6.0 \mathrm{mg}\left(28 \%, \mathrm{mp} \mathrm{176-195}{ }^{\circ} \mathrm{C} \mathrm{dec}\right)\right) .{ }^{1} \mathrm{H} \mathrm{NMR}\left(\mathrm{CDCl}_{3}\right) \delta[7.58$ $(\mathrm{s}), 7.50(\mathrm{~s})(1 \mathrm{H})], 7.06(3 \mathrm{H}, \mathrm{m}),[6.87(\mathrm{~s}), 6.85(\mathrm{~s})(1 \mathrm{H})],[6.64(\mathrm{~s}), 6.54(\mathrm{~s})(1 \mathrm{H})], 6.02(2 \mathrm{H}, \mathrm{m})$, [6.02 (s), $5.92(\mathrm{~s})(1 \mathrm{H})],[4.40(\mathrm{dd}, J=6.8,6.8 \mathrm{~Hz}), 5.35(\mathrm{dd}, J=6.8,5.6 \mathrm{~Hz})(1 \mathrm{H})],[4.74(\mathrm{dd}, J$ 
$=7.6,7.6 \mathrm{~Hz}), 4.54(\mathrm{dd}, J=8.0,8.0 \mathrm{~Hz})(1 \mathrm{H})],[4.07(\mathrm{dd}, J=7.6,5.2 \mathrm{~Hz}), 3.82(\mathrm{dd}, J=7.6,7.6$ $\mathrm{Hz})(1 \mathrm{H})] ;{ }^{13} \mathrm{C}$ NMR $\left(100 \mathrm{MHz}, \mathrm{CDCl}_{3}\right)(160.38,160.27),(155.34,155.25),(154.96,154.90)$, (152.10, 151.77), (148.97, 148.84), 148.01, (130.44, 129.46), (126.70, 126.55), (120.96, 120.76), (112.28, 112.20), (110.74, 109.61), (108.29, 108.22), 106.92, (106.72, 106.69), (105.05, 104.65), (104.76, 104.70), (101.40, 101.37), (73.76, 73.28), (70.62, 70.12); FTIR (neat) 3423, 2960, 2923, 1722, 1605, 1400, 1260, 1094, 1029, 869, $801 \mathrm{~cm}^{-1}$; MS m/z $435\left(\mathrm{MH}^{+},{ }^{81} \mathrm{Br}\right), 433\left(\mathrm{MH}^{+}\right.$, $\left.{ }^{79} \mathrm{Br}\right)$.

Bhc-diol-acetophenone (16c). Bhc-diol $(20 \mathrm{mg}, 0.07 \mathrm{mmol})$, PPTS (33 mg, $0.14 \mathrm{mmol})$, acetophenone (15c, $40 \mu \mathrm{L}, 0.35 \mathrm{mmol})$; yield $\left.=6.0 \mathrm{mg}\left(22 \%, \mathrm{mp} 170-220{ }^{\circ} \mathrm{C} \mathrm{dec}\right)\right) .{ }^{1} \mathrm{H}$ NMR $\left(\mathrm{CDCl}_{3}\right) \delta 7.51(6 \mathrm{H}, \mathrm{m}),[7.05(\mathrm{~s}), 7.01(\mathrm{~s})(1 \mathrm{H})],[6.64(\mathrm{~s}), 6.40(\mathrm{~s})(1 \mathrm{H})],[5.40(\mathrm{dd}, J=7.2,7.2$ $\mathrm{Hz}), 5.07(\mathrm{dd}, J=7.6,5.2 \mathrm{~Hz})(1 \mathrm{H})],[4.65(\mathrm{dd}, J=8.8,6.8 \mathrm{~Hz}), 4.24(\mathrm{dd}, J=8.0,8.0 \mathrm{~Hz})(1 \mathrm{H})]$, [3.89 (dd, $J=8.0,5.2 \mathrm{~Hz}), 3.71(\mathrm{dd}, J=8.0,8.0 \mathrm{~Hz})(1 \mathrm{H})],[1.83(\mathrm{~s}), 1.78(\mathrm{~s})(3 \mathrm{H})] ;{ }^{13} \mathrm{C}$ NMR $\left(100 \mathrm{MHz}, \mathrm{CDCl}_{3}\right)$ 160.59, 155.40, (154.81, 154.63), 152.56, 141.98, (128.60, 128.53), (128.47, 128.34), 126.66, 125.27, 124.70, 112.15, 111.11, 110.20, 106.63, (104.61, 104.51), 74.41, 72.94, (69.86, 69.33), (28.16, 27.74); FTIR (neat) 3416, 2922, 1697, 1602, 1395, 1308, 1224, 1155, $1096,874,760,699 \mathrm{~cm}^{-1}$; MS m/z $405\left(\mathrm{MH}^{+},{ }^{81} \mathrm{Br}\right), 403\left(\mathrm{MH}^{+},{ }^{79} \mathrm{Br}\right)$.

Bhc-diol-cyclohexanone (16d). Bhc-diol (15 mg, $0.05 \mathrm{mmol})$, PPTS (13 mg, $0.05 \mathrm{mmol})$, cyclohexanone (15d, $10 \mu \mathrm{L}, 0.10 \mathrm{mmol})$; yield $\left.=7.5 \mathrm{mg}\left(39 \%, \mathrm{mp} 180-230{ }^{\circ} \mathrm{C} \mathrm{dec}\right)\right) .{ }^{1} \mathrm{H} \mathrm{NMR}$ $\left(\mathrm{CDCl}_{3}\right) \delta 7.54(1 \mathrm{H}, \mathrm{s}), 7.04(1 \mathrm{H}, \mathrm{s}), 6.58(1 \mathrm{H}, \mathrm{s}), 5.26(1 \mathrm{H}, \mathrm{dd}, J=8.0,8.0 \mathrm{~Hz}), 4.53(1 \mathrm{H}, \mathrm{dd}, J$ $=8.0,8.0 \mathrm{~Hz}), 3.77(1 \mathrm{H}, \mathrm{dd}, J=8.0,8.0 \mathrm{~Hz}), 1.70(10 \mathrm{H}, \mathrm{m}) ;{ }^{13} \mathrm{C}$ NMR $\left(100 \mathrm{MHz}, \mathrm{CDCl}_{3}\right)$ 160.66, 155.26, 154.72, 152.69, 126.63, 112.38, 111.56, 109.89, 106.62, 104.60, 72.94, 69.09, 35.67, 34.81, 25.01, 23.89, 23.79; FTIR (neat) 3386, 2935, 2862, 1707, 1604, 1395, 1272, 1231, $1155,1107,1036,875,700 \mathrm{~cm}^{-1}$; MS m/z $383\left(\mathrm{MH}^{+},{ }^{81} \mathrm{Br}\right), 381\left(\mathrm{MH}^{+},{ }^{79} \mathrm{Br}\right)$.

Determination of the Quantum Efficiency for Single Photon Excitation. KMOPS-buffered solutions $(3 \mathrm{~mL})$ of the substrates $(100 \mu \mathrm{M})$ in quartz cuvettes (21-Q-10, Starna, Atascadero, CA) were irradiated with 365-nm UV light from a mercury lamp (Spectroline SB-100P; Spectronics Corporation, Westbury, NY). The spectral output of the lamp is a distribution across the UV-A wavelengths $(310-400 \mathrm{~nm})$ with an intense band at $365 \mathrm{~nm}$. The duration of each irradiation period ranged from 5 to $360 \mathrm{~s}$. After each period of irradiation, a $20 \mu \mathrm{l}$ aliquot of the solution was removed for analysis by HPLC, using an external standard method to determine concentrations. The compound was eluted with an isocratic mixture of 50\% acetonitrile and $50 \%$ water containing $0.1 \%$ trifluoroacetic acid (flow rate of $1 \mathrm{~mL} / \mathrm{min}$ ). Absorbance was detected at $325 \mathrm{~nm}(\mathbf{1 6 a}), 328 \mathrm{~nm}(\mathbf{1 6 c}$ and $\mathbf{1 6 d})$, and $329 \mathrm{~nm}(\mathbf{1 6 b})$. The progress curves were plotted as simple decaying exponentials. Quantum efficiencies $\left(Q_{u l}\right)$ were calculated according to a published method, ${ }^{1}$ using $Q_{u l}=\left(I \sigma_{90 \%}\right)^{-1}$, where $I$ is the irradiation intensity in ein $\cdot \mathrm{cm}^{-2} \cdot \mathrm{s}^{-1}, \sigma$ is the decadic extinction coefficient $\left(10^{3}\right.$ times $\varepsilon$, the molar extinction coefficient) in $\mathrm{cm}^{2} \cdot \mathrm{mol}^{-1}$, and $t_{90 \%}$ is the irradiation time in seconds for $90 \%$ conversion to product. The UV intensity of the lamp $I$ was measured by using potassium ferrioxalate actinometry ${ }^{2}$ in the same setup. Release of piperonal (15b) or acetophenone (15c) was monitored at 313 and $240 \mathrm{~nm}$, respectively, and the progress curves plotted as an exponential rise to max. Concentrations were determined using an external standard. 
Determination of the Dark Hydrolysis Rate. Substrates were dissolved in a KMOPS-buffered solution and stored in the dark at room temperature. HPLC analysis was carried out periodically as described for single photon photolysis.

Control Photolysis Experiments. Piperonal (15b, $97 \mu \mathrm{M})$ and acetophenone (15c, $104 \mu \mathrm{M})$ were each dissolved in KMOPS buffer. A small amount of $\mathrm{MeOH}$ was used as a co-solvent to effect dissolution. The solutions were exposed to the 365-nm mercury lamp for $1 \mathrm{~min}$, and any change in concentration was monitored by HPLC as in the quantum efficiency determination. KMOPS-buffered solutions of Bhc-diol $(\mathbf{1 4}, 100 \mu \mathrm{M})$ and carbonyl compound $(\mathbf{1 5 b}, 104 \mu \mathrm{M}$; 15c, $97 \mu \mathrm{M}$ ) were photolyzed as before, and any changes in concentration of Bhc-diol, piperonal, or acetophenone were monitored by HPLC.

Measurement of the Two-Photon Uncaging Cross-Section. Measurements were carried out in microcuvettes $(10 \times 1 \times 1 \mathrm{~mm}$ illuminated dimensions) with an effective filling volume of $20 \mu \mathrm{L}$ (26.10F-Q-10, Starna, Atascadero, CA), using light from a fs-pulsed and mode-locked Ti:Sapphire laser (Mira 900 pumped by a Verdi, Coherent, Santa Clara, CA) focused on the center of the cuvette chamber with a $25 \mathrm{~mm}$ focal length lens optimized for IR lasers (06LXP003/076, Melles-Griot, Irvine, CA). The two-photon uncaging cross-section $\left(\delta_{u 2}\right)$ was estimated by referencing to fluorescein, a compound with a known two-photon fluorescence quantum yield $\left(Q_{f 2}=0.9 \mathrm{~mol} / \mathrm{ein}\right)$ and absorbance cross-section $\left(\delta_{a F}=30 \mathrm{GM}\right.$ at $\left.740 \mathrm{~nm}\right){ }^{3}$

$$
\delta_{u 2}=\frac{N_{p} \phi Q_{f 2} \delta_{a F} C_{F}}{<F(t)>C_{S}}
$$

where $N_{p}$ is the number of product molecules formed per unit time (molecules/s, determined by HPLC analysis as in the 1-photon analysis); $\Phi$ is the collection efficiency of the detector (SED033 on an IL-1700, International Light, Newburyport, MA) used to measure the fluorescence of fluorescein emitted at a right angle to the beam and passed though a 535/45 nm bandpass filter (Chroma Technologies, Brattleboro, VT); $C_{F}$ is the concentration of fluorescein $(\mathrm{mol} / \mathrm{L}) ;\langle F(t)\rangle$ is the time averaged fluorescent photon flux (photons/s) collected by the detector; and $C_{s}$ is the initial concentration of caged substrate $(\mathrm{mol} / \mathrm{L}){ }^{1}$

(1) Furuta, T.; Wang, S. S.-H.; Dantzker, J. L.; Dore, T. M.; Bybee, W. J.; Callaway, E. M.; Denk, W.; Tsien, R. Y. Proc. Natl. Acad. Sci. USA 1999, 96, 1193-2000.

(2) Hatchard, C. G.; Parker, C. A. Proc. R. Acad. Lond. A 1956, 235, 518-536.

(3) Xu, C.; Webb, W. W. J. Opt. Soc. Am. B 1996, 13, 481-491. 